\title{
Cultivars Response of Flax (Linum usitatissimum L.) to Different Nitrogen Sources in Dry Environment
}

\author{
S.M. Emam \\ Department of Agronomy, Faculty of Agriculture, Fayoum University, Fayoum, Egypt.
}

\begin{abstract}
$\mathbf{T}$ WO YEARS field experiment were carried out at Demo experimental farm, Faculty of Agriculture, Fayoum University, Egypt in 2015/16 and 2016/17 seasons to examine the effect of nitrogen sources as soil application on straw and seed yields as well as seed quality of flax. A split-plot arrangement with three replications was used. Three cultivars of flax i.e., Sakha-1, Sakha-2 and Giza-9 occupied the main plots. While, N-sources, i.e., ammonium nitrate $(23.5 \%)$, urea $(46.5 \%)$ and ammonium sulfate $(20.6 \%)$ distributed in the sub-plot. The obtained results clarified that Sakha-1 gave the highest straw yield and its attributes mean values i.e., plant height, technical stem length and straw yield plant ${ }^{-1}$. While, Sakha- 2 gave the highest mean values for number of branches plant ${ }^{-1}$ and stem diameter. In addition, Sakha-2 cultivar was exceeded the other two cultivars with regard to seed yield and related traits i.e., fruiting zone length, no. of fruiting branches plant ${ }^{-1}$, No. of capsules plant ${ }^{-1}, 1000$-seed weight and seed and oil yield fed $^{-1}$. Ammonium nitrate followed by ammonium sulfate as $\mathrm{N}$-sources gave the highest straw and seed yields and its related traits when compared with urea. Thus, the recommendations of this study are cultivating Sakha- 2 variety and fertilized by ammonium nitrate as $\mathrm{N}$-sources.
\end{abstract}

The obtained results of regression analysis of seed yield indicated that, there are two traits i.e. seed yield plant ${ }^{-1}$ and No. of capsules plant ${ }^{-1}$ in the first season and $\mathrm{Zn} \mathrm{mg} 100 \mathrm{~g}^{-1}$ in the second one, were significantly $(\mathrm{P} \leq 0.001)$ contributed to variation in seed yield feddan.

Keywords: Flax, Cultivars, N-sources, Dry environment.

\section{Introduction}

Flax, Linum usitatissimum L., is one of the oldest agricultural crops in Egypt since the Pharaonic era (Conforti \& Cachaper, 2009). The flax is a dual purposes crop where it is grown for oil and fiber as well as many medical and industrial uses for more than 8,000 years (Karg, 2011). The percentage of oil in flax seeds ranged from 36 to $48 \%$ (Millis, 2002 ) and the protein ranged $\% 20$ to $30 \%$ (Hall et al., 2006). For these multiple uses, there are many varieties and genotypes suitable for many regions and weather conditions in many countries all over the world. Significant differences among flax genotypes were found concerning yields of straw, seed and seed quality under various conditions were found by Sharief et al. (2005), Abou-Zaied \& Mousa (2007), Kandil et al. (2008), Bakry (2009), El-Azzouni \& Zedan (2009), Khalifa et al. (2011), Bakry et al. (2012), Homayouni et al. (2013), Afifi et al. (2014), Gallardo et al. (2014), Bakry et al.
(2015), Elayan et al. (2015), El-Seidy et al. (2015) El-Shafey \& Hassan (2016), El-Borhamy (2016), Nawar et al. (2017) and Sadi et al. (2017).

Under semi-arid conditions and shortage of water supply, appropriate genetic material should be tested for these harsh conditions and appropriate treatments should be used to obtain the highest unit area productivity. The most important of these treatments was enough and good fertilization from different sources. Nitrogen fertilizer is an important element of the plant and there are many sources of nitrogen fertilizers, which differ in their characteristics such as rates of solubility, volatilization and absorption by plants. In canola, Santos et al. (2012) mentioned that the highest average values obtained by applying urea. In clay soil, El-Shazly et al. (2014) found that ureaformaldehyde as a nitrogen source exceeded other $\mathrm{N}$ sources, while the differences between ammonium sulfate and ammonium nitrate were

Corresponding author email: sme00@fayoum.edu.eg 
insignificant on sugar beet characters. In the same soil condition, Soethe et al. (2013) found that urea significantly exceeded ammonium sulfate on number of branches plant ${ }^{-1}$, dry weight plant ${ }^{-1}$, seed index and seed yield ha ${ }^{-1}$. Grant et al. (2016) tested $\mathrm{N}$ fertilizers of urea and urea ammonium nitrate (UAN), as well as ammonium nitrate (AN) on flax and they reported that seed yield was higher with AN than urea. In loamy sand, Zaki et al. (2018) investigate four forms of nitrogen (olive pomace $1.54 \% \mathrm{~N}$, ammonium nitrate $33.5 \% \mathrm{~N}$, ammonium sulfate $20.6 \% \mathrm{~N}$ and urea $46.5 \% \mathrm{~N}$ ) on sugar beet, and they mentioned that ammonium nitrate and ammonium sulfate surpassed urea for most studied traits.

Thus the goal of the present study was to test the cultivars performance of flax yield and seed quality under different $\mathrm{N}$ sources on dry conditions.

\section{Materials and Methods}

Two years field experiment were conducted during 2015/16 and 2016/17 seasons at the Demo Experimental Farm of the Faculty of Agriculture, Fayoum University, Southeast Fayoum (29 $17^{\circ} \mathrm{N}$; $\left.30^{\circ} 53^{\prime} \mathrm{E}\right)$, Egypt to study the of nitrogen fertilizer sources on some flax cultivars. Each experiment includes 9 treatments which were the combinations of 3 flax cultivars and 3 nitrogen fertilizer sources. The split-plot arrangement in (RCBD) with three replications was applied. The main plots were occupied by the flax cultivars (Sakha-1, Sakha-2 and Giza-9), whereas the three nitrogen fertilizer sources (ammonium nitrate $\left(\mathrm{NH}_{4} \mathrm{NO}_{3}\right) 33.5 \%$, urea $\left(\mathrm{CH}_{4} \mathrm{~N}_{2} \mathrm{O}\right) 46.5 \%$ and ammonium sulfate $\left((\mathrm{NH} 4)_{2} \mathrm{SO}_{4}\right) \quad 20.6 \%$ were randomly distributed in the sub-plots. The sub-plot comprised $6 \mathrm{~m}^{2}$ $\left(1 / 700\right.$ feddan, one feddan $\left.=4200 \mathrm{~m}^{2}\right)$ with $3 \mathrm{~m}$ long and $2 \mathrm{~m}$ wide. Healthy seeds of three flax (Linum usitatissimum L.) cultivars were broadcasting on 7 and 10 November in the $1^{\text {st }}$ and $2^{\text {nd }}$ seasons, respectively. Flax varieties were obtained from the Field Crop Research Institute, Agricultural Research Centre, Giza, Egypt and were sown at the equivalent of $70 \mathrm{~kg}$ fed $^{-1}$ to achieve the recommended planting density. The preceding crop was maize in both seasons.

The experimental site was cultivated under conventional tillage. Calcium supper-phosphate $\left(15.5 \% \mathrm{P}_{2} \mathrm{O}_{5}\right)$ at the rate of $150 \mathrm{~kg} \mathrm{fed}^{-1}$ was added during tillage and before ridging. Nitrogen was applied equally in two doses at the rate of
$75 \mathrm{~kg} \mathrm{fed}^{-1}$ (according to previous treatments for all nitrogen sources) before the second and third irrigation. All other recommended agricultural practices in a newly-reclaimed soil for flax production were adopted throughout the growing seasons according to the bulletin of Egyptian Ministry of Agriculture (1086/2007). Soil physical and chemical properties of the experimental site were presented in Table 1. Analytical procedures were those recommended by Wilde et al. (1985).

\section{Measurements of flax yields}

At maturity, ten singular plants were randomly taken from each experimental plot to register the following traits:

- Straw yield and related traits (plant height, technical stem length, stem diameter, No. of branches plant ${ }^{-1}$ and straw plant ${ }^{-1}$.

- $\quad$ Seed yield and related traits (fruiting zone length, No. of fruiting branches plant ${ }^{-1}$, No. of capsules plant ${ }^{-1}$ and seed yield plant ${ }^{-1}$.

The plants grown on the middle of each subplot were used to determine the following traits:

- $\quad$ 1000-seed weight (g), straw yield fed $^{-1}$ (ton) and seed yield $\mathrm{fed}^{-1}(\mathrm{~kg})$.

- $\quad$ Oil yield $\mathrm{fed}^{-1}(\mathrm{~kg})$ was calculated by multiplying seed yield by seed oil \%.

- $\quad$ Seed quality (seed oil \%, Fe, Mn and Zn (mg $100 \mathrm{~g}^{-1}$ ).

Seed oil \% was determined by Soxhlet extraction device using solvent of petroleum ether and then the seed oil \% was determined on dry weight basis according to A.O.A.C (1990). To estimate the micronutrients (i.e., iron $=\mathrm{Fe}$, manganese $=\mathrm{Mn}$ and zinc $=\mathrm{Zn}$ ) contents, flax seeds were dried and grounded to powdered form. The contents of micronutrients were assessed by an Atomic Absorption Spectrophotometer device (Perkin Elmer, Model-3300) as explained by Chapman \& Pratt (1961) method.

\section{Statistical analysis}

The analysis of variance (ANOVA) technique for the split-plot arrangement was used to statistically analyzed all data as published by Gomez \& Gomez (1984), using the GenSt at $12^{\text {th }}$ edition software . LSD test was applied to test the treatment means differences at 5 and $1 \%$ level of probability. 
TABLE 1. Some physical and chemical characteristics of the experimental soil in the two growing winter seasons 2015/2016 and 2016/2017.

\begin{tabular}{|c|c|c|}
\hline Properties & $2015 / 2016$ & 2016/2017 \\
\hline \multicolumn{3}{|l|}{ Particle size distribution } \\
\hline Sand $\%$ & 66.07 & 69.07 \\
\hline Silt \% & 15.08 & 16.08 \\
\hline Clay $\%$ & 18.85 & 17.85 \\
\hline Soil texture & Sandy loam & Sandy loam \\
\hline \multicolumn{3}{|l|}{ Chemical properties: } \\
\hline Bulk density $\left(\mathrm{g} \mathrm{cm}^{-3}\right)$ & 1.40 & 1.44 \\
\hline $\mathrm{K}_{\mathrm{sat}}\left(\mathrm{cm} \mathrm{h}^{-1}\right)$ & 3.26 & 2.41 \\
\hline $\mathrm{pH}$ & 7.65 & 7.60 \\
\hline $\mathrm{Ec}_{\mathrm{e}}\left(\mathrm{dS} \mathrm{m}^{-1}\right)$ & 3.18 & 2.97 \\
\hline $\mathrm{CaCO}_{3}(\%)$ & 7.90 & 7.84 \\
\hline Organic matter (\%) & 0.97 & 0.95 \\
\hline Total N (mg kg-1) & 0.04 & 0.041 \\
\hline Available P $\left(\mathrm{mg} \mathrm{kg}^{-1}\right)$ & 3.25 & 3.54 \\
\hline Available $\mathrm{K}\left(\mathrm{mg} \mathrm{kg}^{-1}\right)$ & 42.57 & 40.12 \\
\hline Available $\mathrm{Mn}\left(\mathrm{mg} \mathrm{kg}^{-1}\right)$ & 1.26 & 1.55 \\
\hline Available Fe $\left(\mathrm{mg} \mathrm{kg}^{-1}\right)$ & 5.65 & 4.92 \\
\hline Available $\mathrm{Zn}\left(\mathrm{mg} \mathrm{kg}^{-1}\right)$ & 0.87 & 0.84 \\
\hline
\end{tabular}

\section{Results and Discussion}

Straw yield and related traits

Effect of flax cultivars

Data in Table 2 showed that straw yield and its attributes (i.e., plant height, technical length, stem diameter, number of branches plant ${ }^{-1}$ and strawyield plant $^{-1}$ ) were affected significantly by varietal differences in both season. Sakha-1 surpassed Giza-9 in plant height, technical stem length, stem diameter, number of branches plant $^{-1}$, straw yield per plant and per feddan in both seasons. Range of increment was 19.36, $22.98,9.43,11.46,40.29$ and $32.78 \%$ in the first season and 15.76, 19.11, 17.93, 8.02, 47.47 and $33.19 \%$, in the second one, respectively. On the other hand, Sakha-2 gave significantly the higher stem diameter and number of branches plant ${ }^{-1}$ in both seasons. Elayan et al. (2015) come to the same results, when found that Sakh-1 surpassed Sakh-2 concerning plant height, technical stem length, straw yield per plant and per feddan. In addition, Afifi et al. (2014) reported that Sahk1 significantly exceeded Giza- 8 in plant height and straw yield $\mathrm{fed}^{-1}$. On the other hand, Giza-9 gave significantly the lowest mean values than other cultivars for previous traits in the two seasons. In conclusion, the data clearly indicated that Sakha-1 surpassed the other two cultivars in respect of straw yield and its components, while Giza-9 recorded the lowest values of straw yield $\mathrm{fed}^{-1}$ as well as straw yield components. Varietal differences were observed by many researchers among them Sharief et al. (2005), Abou-Zaied \& Mousa (2007), Kandil et al. (2008), Bakry (2009), El-Azzouni \& Zedan (2009), Khalifa et al. (2011), Bakry et al. (2012), Mirshekari et al. (2012), Homayouni et al. (2013), Gallardo et al. (2014), Bakry et al. (2015), El-Seidy et al. (2015), El-Shafey \& Hassan (2016), El-Borhamy (2016), Nawar et al. (2017) and Sadi et al. (2017).

\section{Effect of nitrogen sources}

Data in Table 2 clarified that nitrogen fertilizer sources have significant effect on straw yield and its traits in both seasons of experimentation. Such effect may by attribute to the increase in number of internodes and/or internode length since nitrogen increase the meristematic activity of plant. $\mathrm{N}$ fertilizer in the form of ammonium nitrate (AN) gave the highest values followed by ammonium sulfate (AS). Urea as $\mathrm{N}$ fertilizer source gave significantly the lowest straw yield and its attributes mean values in the two seasons. AN surpassed Urea for plant height, technical stem length, stem diameter, number of branches plant ${ }^{-1}$, straw yield plant ${ }^{-1}$ and straw yield fed ${ }^{-1}$ by 10.84 , $13.63,29.33,52.66,29.11$ and $35.27 \%$ in the first 
season and by $11.06,15.96,24.48,49.10,44.22$ and $27.5 \%$ in the second one. The increase in flax straw yield and its attributes due to AN followed by AS form might be attributed to its increased the availability of nutrients and efficiency improved uptake, thus increased growth rate resulted in raising plant height and straw yield plant ${ }^{-1}$ which led to increasing straw yield fed ${ }^{-1}$, also the increase in straw yield might be attributed to the main role of $\mathrm{N}$ in stimulating and raising plant growth and productivity, therefore increased straw yield. Under different soil type conditions, the same trend was found by Soethe et al. (2013) and Grant et al. (2016) on flax, Santos et al. (2012) on canola and El-Shazly et al. (2014) and Zaki et al. (2018) on sugar beet.

\section{Effect of the interaction}

Figure 1 illustrated that a significant effect due to the interaction between flax cultivars and nitrogen sources for stem diameter in the $1^{\text {st }}$ growing season and straw yield plant ${ }^{-1}$ and straw yield $\mathrm{fed}^{-1}$ in the $2^{\text {nd }}$ one was found. It is clearly observed that the highest values for most studied characteristics of straw yield and its components were obtained from Sakha-1 fertilized by ammonium nitrate or ammonium sulfate.

TABLE 2. Mean values of flax cultivars straw yield and its components as affected bynitrogen sources in 2015/2016 and $2016 / 2017$ seasons.

\begin{tabular}{|c|c|c|c|c|c|c|}
\hline Treatments & $\begin{array}{l}\text { Plant height } \\
\quad(\mathrm{cm})\end{array}$ & $\begin{array}{l}\text { Technical stem } \\
\text { length }(\mathrm{cm})\end{array}$ & $\begin{array}{c}\text { Stem } \\
\text { diameter }(\mathrm{cm})\end{array}$ & $\begin{array}{c}\text { No of } \\
\text { branches } \\
\text { plant }^{-1}\end{array}$ & $\begin{array}{c}\text { Straw yield } \\
\text { plant }^{-1} \\
\text { (g) }\end{array}$ & $\begin{array}{l}\text { Straw yield } \\
\text { ton } \text { fed }^{-1}\end{array}$ \\
\hline \multicolumn{7}{|c|}{$2015 / 2016$ season } \\
\hline Varieties (V) & $*$ & $*$ & NS. & NS. & $* *$ & NS. \\
\hline Sakh-1 & 113.89 & 82.36 & 1.74 & 2.14 & 2.89 & 3.20 \\
\hline Sakh-2 & 106.19 & 72.66 & 1.92 & 2.56 & 2.57 & 2.95 \\
\hline Giza-9 & 95.42 & 66.97 & 1.59 & 1.92 & 2.06 & 2.41 \\
\hline LSD 0.05 & 10.70 & 7.72 & - & - & 0.37 & - \\
\hline N sources (B) & $*$ & $* *$ & $* *$ & NS. & $* *$ & $* *$ \\
\hline A. Nitrate & 109.33 & 77.93 & 1.94 & 2.58 & 2.75 & 3.26 \\
\hline Urea & 98.64 & 68.58 & 1.50 & 1.69 & 2.13 & 2.41 \\
\hline A. Sulfate & 107.53 & 75.48 & 1.81 & 2.33 & 2.64 & 2.90 \\
\hline LSD 0.05 & 6.87 & 5.08 & 0.19 & - & 0.31 & 0.27 \\
\hline Interaction $(\mathbf{A} * \mathbf{B})$ & NS. & NS. & $0.33 *$ & NS. & NS. & NS. \\
\hline \multicolumn{7}{|c|}{$2016 / 2017$ season } \\
\hline Varieties (V) & $*$ & $*$ & $* *$ & NS. & $* *$ & NS. \\
\hline Sakh-1 & 108.79 & 80.29 & 1.71 & 2.02 & 2.92 & 3.13 \\
\hline Sakh-2 & 105.36 & 72.96 & 1.81 & 2.38 & 2.50 & 2.87 \\
\hline Giza-9 & 93.98 & 67.41 & 1.45 & 1.87 & 1.98 & 2.35 \\
\hline LSD 0.05 & 8.36 & 8.70 & 0.13 & - & 0.45 & - \\
\hline N sources (B) & $* *$ & $* *$ & $* *$ & NS. & $* *$ & $* *$ \\
\hline A. Nitrate & 107.71 & 78.39 & 1.78 & 2.49 & 2.87 & 3.06 \\
\hline Urea & 96.98 & 67.60 & 1.43 & 1.67 & 1.99 & 2.40 \\
\hline A. Sulfate & 103.44 & 74.68 & 1.76 & 2.11 & 2.54 & 2.89 \\
\hline LSD 0.05 & 4.76 & 3.44 & 0.20 & - & 0.16 & 0.35 \\
\hline Interaction $(A * B)$ & NS. & NS. & NS. & NS. & $0.28 * *$ & $0.61 *$ \\
\hline
\end{tabular}

${ }^{*} \mathrm{P} \leq 0.05$, ${ }^{* *} \mathrm{P} \leq 0.01$ and NS.: Not significant. 


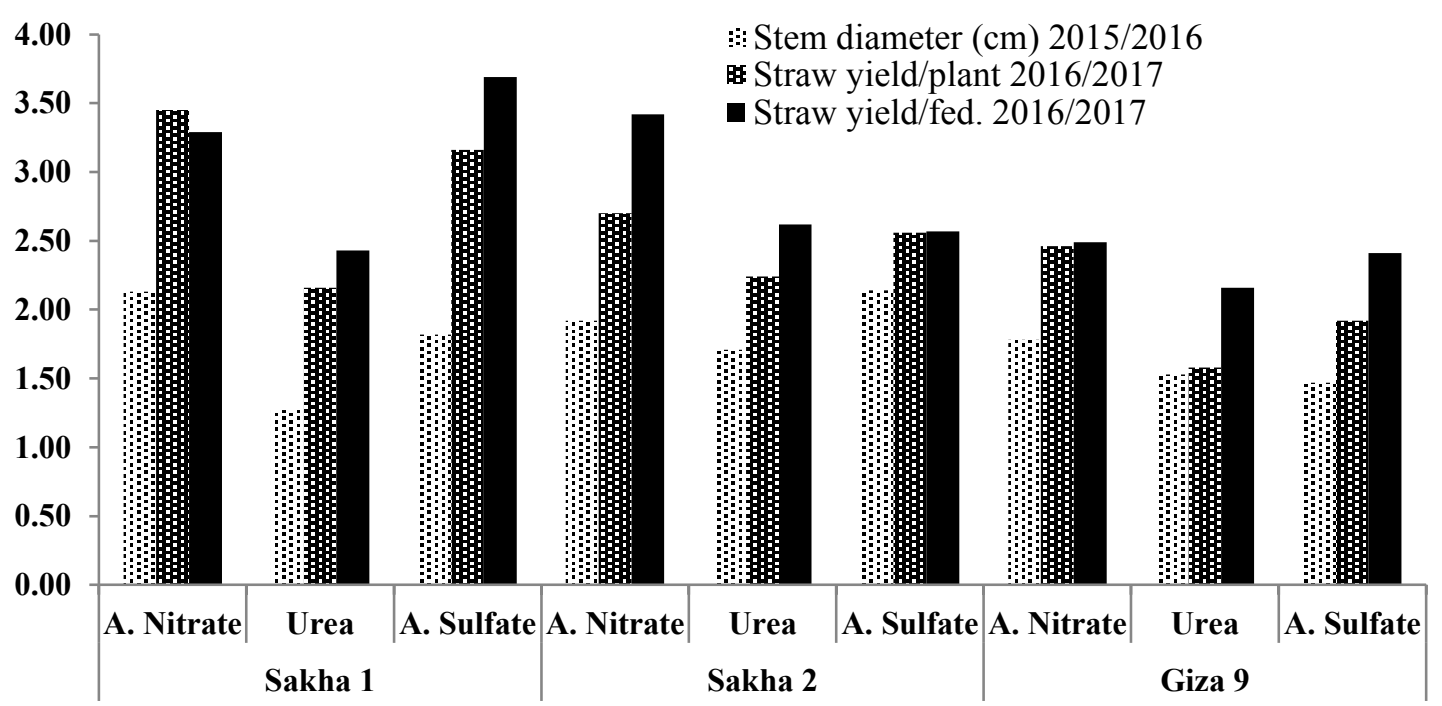

Fig. 1. Effect of the interaction between flax cultivars and nitrogen sources on straw yield and its components.

\section{Seed yield and related traits}

Effect of flax cultivars

Seed yield and its attributes of flax cultivars as affected by $\mathrm{N}$ sources and their interaction are given in Table 3. The differences among cultivars were significant for No. of fruiting branches plant ${ }^{-1}$, No. of capsules plant ${ }^{-1}, 1000$-seed weight (g) and seed yield plant ${ }^{-1}(\mathrm{~g})$ in the first seasons and yields of seed and oil $\left(\mathrm{kg} \mathrm{fed}^{-1}\right)$ in the second one. Sakh-2 gave significantly the highest values of number of fruiting branches plant ${ }^{-1}$ (8.64 and 8.58) number of capsules plant ${ }^{-1}$ (22.86 and 21.00), 1000-seed weight $(9.27$ and $9.16 \mathrm{~g})$, seed yield plant ${ }^{-1}(1.70$ and $1.84 \mathrm{~g})$, seed yield $(729.60$ and $705.07 \mathrm{~kg}$ $\left.\mathrm{fed}^{-1}\right)$ oil yield (295.09 and $\left.283.94 \mathrm{~kg} \mathrm{fed}^{-1}\right)$ in the $1^{\text {st }}$ and $2^{\text {nd }}$ seasons, respectively. These results are go on line with those obtained by Afifi et al. (2014) who mentioned that Sahk-1 significantly exceeded Giza-8 in number of capsules plant ${ }^{-1}$ and seed yield plant ${ }^{-1}$, also Elayan et al. (2015) stated that Sakh-1 significantly surpassed the other two varieties in seed yield and its attributes over the two seasons. More than one investigator obtained the same conclusion among them Sharief et al. (2005), Abou-Zaied \& Mousa (2007), Kandil et al. (2008), Bakry (2009), El-Azzouni \& Zedan (2009), Khalifa et al. (2011), Bakry et al. (2012), Mirshekari et al. (2012). Homayouni et al. (2013), Gallardo et al. (2014), Bakry et al. (2015), ElSeidy et al. (2015) El-Shafey \& Hassan (2016), El-Borhamy (2016), Nawar et al. (2017) and Sadi et al. (2017).

\footnotetext{
Effect of nitrogen sources

In both seasons, the differences in seed
}

yield and its attributes due to nitrogen sources were significant (Table 3). Comparison among nitrogen source means according to LSD test in both seasons indicated that applied ammonium nitrate as $\mathrm{N}$ source significantly exceeded the other two $\mathrm{N}$ forms in all seed yield traits which in par with the form of ammonium sulfate in some traits. The observed increase in the case of ammonium nitrate application possibly because it is one of the best nitrogen fertilizers that resulted in an increase nitrogen uptake that is essential for building up protoplasm and proteins which induce cell division and initiate meristematic activity. This effect resulted in an increase in cell number and cell size with an overall increase in leaf production. It can be noticed that the lowest mean values for all studied traits were obtained by $\mathrm{N}$ sources of urea. These results are go in line with those obtained by Soethe et al. (2013) and Grant et al. (2016) on flax, Santos et al. (2012) on canola, El-Shazly et al. (2014) and Zaki et al. (2018) on sugar beet under different soil types or conditions.

\section{Effect of the interaction}

The interaction of flax cultivars and nitrogen sources on seed yield and related traits was significant on number of fruiting branches plant ${ }^{-1}$, in the two seasons and seed yield plant ${ }^{-1}$ and seed yield fed ${ }^{-1}$ as well as oil yield fed ${ }^{-1}$ only in the first one (Fig. 2 A, B). According to LSD test nitrogen application at the form of ammonium nitrate gave significantly the highest values under all flax cultivars. 
TABLE 3. Mean values of flax varieties seed yield and its components as affected by nitrogensources grown in 2015/2016 and 2016/2017 seasons.

\begin{tabular}{|c|c|c|c|c|c|c|c|}
\hline Treatments & $\begin{array}{l}\text { Fruiting zone } \\
\text { length }(\mathbf{c m})\end{array}$ & $\begin{array}{c}\text { No of fruiting } \\
\text { branches plant }^{-1}\end{array}$ & $\begin{array}{c}\text { No of } \\
\text { capsules } \\
\text { plant }^{-1}\end{array}$ & $\begin{array}{l}\text { 1000-seed } \\
\text { weight (g) }\end{array}$ & $\begin{array}{l}\text { Seed yield } \\
\text { plant }^{-1} \\
\text { (g) }\end{array}$ & $\begin{array}{c}\text { Seed yield } \\
\left(\mathrm{kg} \mathrm{fed}^{-1}\right)\end{array}$ & $\begin{array}{l}\text { Oil yield } \\
\left(\mathrm{kg} \mathrm{fed}^{-1}\right)\end{array}$ \\
\hline \multicolumn{8}{|c|}{$2015 / 2016$ season } \\
\hline Varieties (V) & NS. & $*$ & $* *$ & $*$ & $* *$ & NS. & NS. \\
\hline Sakh 1 & 31.53 & 7.03 & 18.44 & 8.48 & 1.34 & 636.08 & 251.75 \\
\hline Sakh 2 & 33.53 & 8.64 & 22.86 & 9.27 & 1.70 & 729.60 & 295.09 \\
\hline Giza 9 & 28.44 & 5.89 & 15.58 & 7.50 & 1.26 & 525.73 & 201.94 \\
\hline LSD 0.05 & - & 1.71 & 2.66 & 1.28 & 0.18 & - & - \\
\hline N sources $(B)$ & NS. & $* *$ & $* *$ & $* *$ & $* *$ & $* *$ & $* *$ \\
\hline A. Nitrate & 31.40 & 8.39 & 21.17 & 9.47 & 1.62 & 722.08 & 291.76 \\
\hline Urea & 30.06 & 5.72 & 16.08 & 7.04 & 1.18 & 489.64 & 188.03 \\
\hline A. Sulfate & 32.05 & 7.45 & 19.64 & 8.73 & 1.50 & 679.69 & 268.99 \\
\hline LSD 0.05 & - & 0.82 & 2.77 & 0.72 & 0.10 & 60.31 & 23.67 \\
\hline $\begin{array}{l}\text { Interaction } \\
(\mathrm{A} * \mathrm{~B}) \\
\end{array}$ & NS. & $1.42 *$ & NS. & NS. & $0.17 * *$ & $104.46^{*}$ & $40.99 \%$ \\
\hline \multicolumn{8}{|c|}{ 2016/2017 season } \\
\hline Varieties (V) & NS. & $*$ & $*$ & $*$ & $*$ & $*$ & $*$ \\
\hline Sakh 1 & 28.50 & 6.91 & 17.73 & 8.39 & 1.53 & 620.82 & 245.44 \\
\hline Sakh 2 & 32.40 & 8.58 & 21.00 & 9.16 & 1.84 & 705.07 & 283.94 \\
\hline Giza 9 & 26.57 & 5.67 & 15.34 & 7.45 & 1.30 & 472.89 & 180.68 \\
\hline LSD 0.05 & - & 1.50 & 3.10 & 1.17 & 0.31 & 133.43 & $\mathbf{5 3 . 8 7}$ \\
\hline N sources $(\mathrm{B})$ & NS. & $* *$ & $* *$ & $* *$ & $* *$ & $* *$ & $* *$ \\
\hline A. Nitrate & 29.32 & 8.36 & 19.69 & 9.30 & 1.77 & 707.68 & 284.68 \\
\hline Urea & 29.38 & 5.48 & 15.81 & 7.00 & 1.27 & 485.89 & 185.76 \\
\hline A. Sulfate & 28.77 & 7.32 & 18.57 & 8.69 & 1.63 & 605.21 & 239.63 \\
\hline LSD 0.05 & - & 0.47 & 1.85 & 0.39 & 0.24 & 129.21 & 48.52 \\
\hline $\begin{array}{l}\text { Interaction } \\
\left(A^{*} B\right)\end{array}$ & NS. & $0.81 *$ & NS. & NS. & NS. & NS. & NS. \\
\hline
\end{tabular}

$* \mathrm{P} \leq 0.05, * * \mathrm{P} \leq 0.01$ and NS.: Not significant.

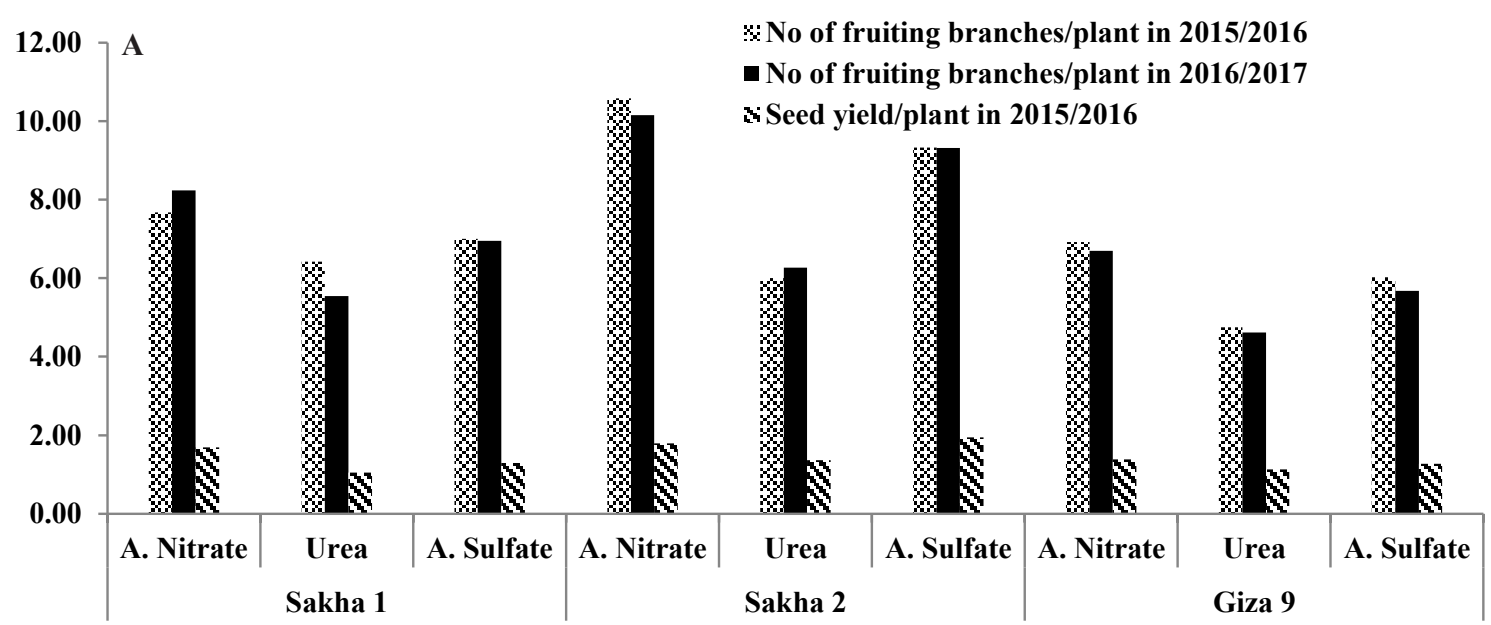




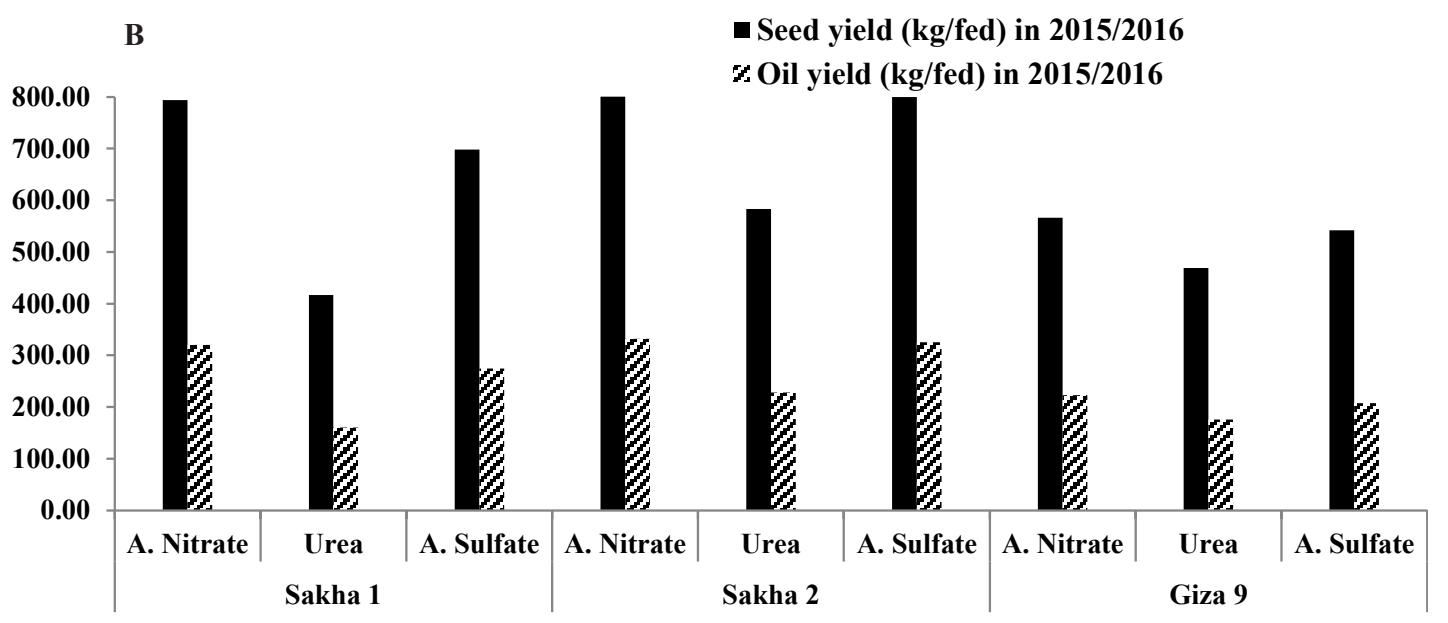

Fig. 2 (A, B). Effect of the interaction between flax genotypes and nitrogen sources on seed yield and its components.

\section{Seed quality}

Effect of flax cultivars

The influences of cultivars, nitrogen sources and their interaction on seed quality in 2015/2016 and 2016/2017 seasons are given in Table 4. There were significant differences among flax cultivars in regard to seed content of Mn mg 100 $\mathrm{g}^{-1}$ in the first season and $\mathrm{Fe} \mathrm{mg} 100 \mathrm{~g}^{-1}$ in the second season. Furthermore, the same trend was observed in both seasons for seed content of $\mathrm{Zn}$ mg $100 \mathrm{~g}^{-1}$ and oil \%. LSD test indicated that Sakh2 gave significantly the highest trait means of $\mathrm{Mn}$

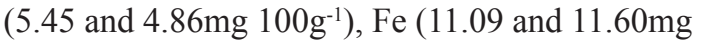
$\left.100 \mathrm{~g}^{-1}\right), \mathrm{Zn}$ (11.92 and 9.38) and oil \% (40.30 and $40.12 \%$ ) in the first and second seasons, respectively. The present findings are in harmony with the work done by Kandil et al. (2008), Bakry (2009), Khan et al. (2010), Khalifa et al. (2011), Bakry et al. (2012), Mirshekari et al. (2012), Afifi et al. (2014), Gallardo et al. (2014), Elayan et al. (2015), Bakry et al. (2015), El-Seidy et al. (2015), El-Shafey \& Hassan (2016), El-Borhamy (2016) and Sadi et al. (2017).

\section{Effect of nitrogen sources}

In Table 4 it is worthy to note that nitrogen sources had a significant effect on seed content of $\mathrm{Mn}, \mathrm{Fe}$ and $\mathrm{Zn}\left(\mathrm{mg} 100 \mathrm{~g}^{-1}\right)$ as well as oil \% except seed $\mathrm{Zn}$ content in the $1^{\text {st }}$ season, this effect was not significant. Comparison between averages of seed chemical composition as affected by nitrogen scourers reflected one trend in both seasons. Results illustrated that ammonium nitrate resulted in a statistically increase in seed quality when compared with urea. LSD test indicate that the application of urea was significantly lower in seed quality traits than other two $\mathrm{N}$ forms which significantly vary from each other with few exceptions. The present findings are in conformance with those of Khan et al. (2010) and Afifi et al. (2014).

\section{Effect of the interaction}

The analysis of variance clarified that there was a significant interaction between both factors under study on seed Mn content in both seasons and seed Fe content only in the first one (Fig. 3). The highest mean values were obtained when Sakh-2 fertilized by ammonium nitrate in both seasons. Similar trend was described by Soethe et al. (2013) and Grant et al. (2016).

\section{Yield analysis \\ Correlation analysis among flax straw yield traits}

Table 5 shows the simple correlation coefficients between straw yield and related traits in the two seasons. In general, straw yield ton $\mathrm{fed}^{-1}$ positively correlated with plant height, technical stem length, stem diameter and straw yield plant $^{-1}$ in both seasons, while this trend was not significant with number of branches plant ${ }^{-1}$. These findings are in concordance with those obtained by Tadesse et al. (2009), Kumar \& Paul (2016) and Kumar et al. (2018). Data presented in Table 6 clarified that, there are two traits i.e., technical stem length and stem diameter in 2015/2016 season and straw yield plant $^{-1}$ in 2016/2017 season, were significantly $(\mathrm{P} \leq 0.001)$ contributed to variation in straw yield fed $^{-1}$. It also noticed that $65.90 \%$ of the total straw yield ${ }^{-1}$ variations could be linearly related technical stem length and stem diameter in 2015/2016 season and 38.90\% straw yield plant ${ }^{-1}$ in 2016/2017 season. 


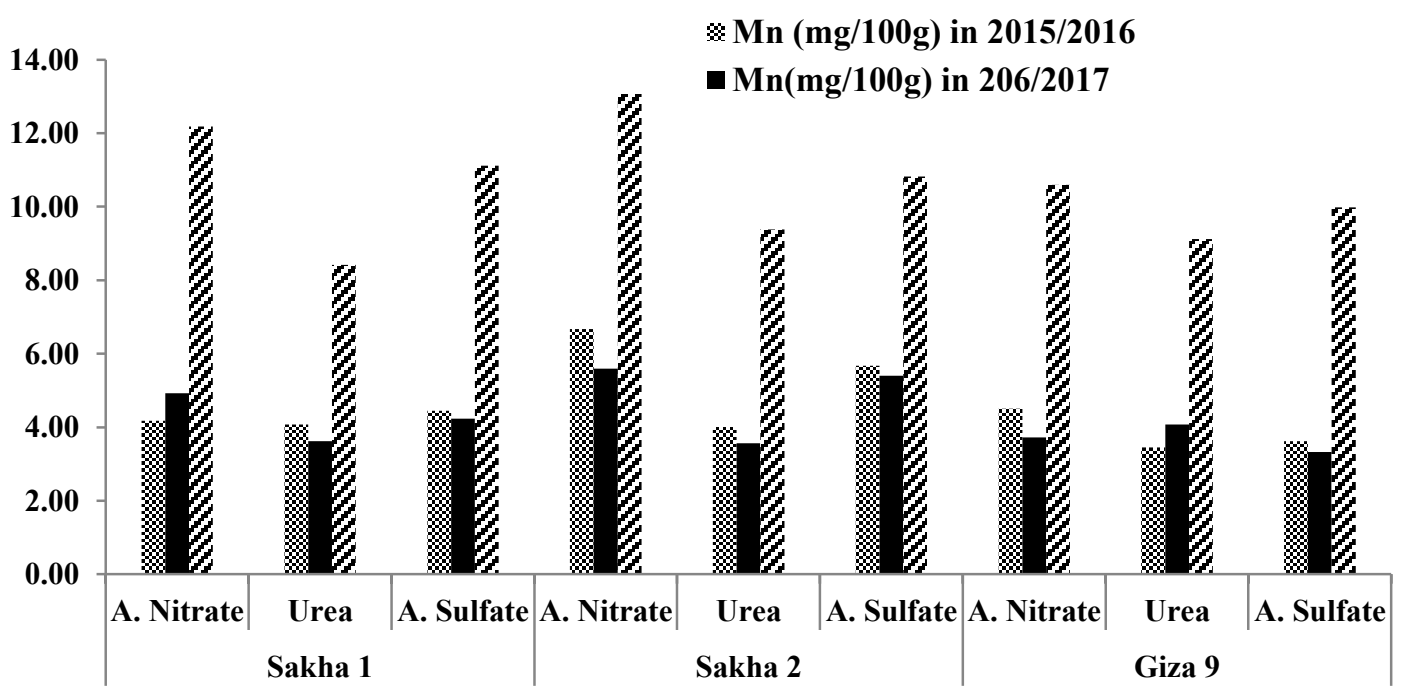

Fig. 3. Effect of the interaction between flax varieties and nitrogen sources on seed chemical composition.

TABLE 4. Mean values of flax cultivars seed quality as affected by nitrogen sources in 2015/2016 and 2016/2017 seasons.

\begin{tabular}{|c|c|c|c|c|}
\hline Treatments & $\begin{array}{c}\text { Mn } \\
\mathrm{mg} 100 \mathrm{~g}^{-1}\end{array}$ & $\begin{array}{c}\mathrm{Fe} \\
\mathrm{mg} \mathrm{100g}^{-1}\end{array}$ & $\begin{array}{c}\mathrm{Zn} \\
\mathrm{mg} \mathrm{100g}^{-1}\end{array}$ & $\begin{array}{l}\text { Oil } \\
\%\end{array}$ \\
\hline \multicolumn{5}{|c|}{$2015 / 2016$ season } \\
\hline Varieties (V) & $*$ & NS. & $* *$ & $*$ \\
\hline Sakh 1 & 4.24 & 10.57 & 10.88 & 39.42 \\
\hline Sakh 2 & 5.45 & 11.09 & 11.92 & 40.30 \\
\hline Giza 9 & 3.86 & 9.90 & 9.16 & 38.35 \\
\hline LSD 0.05 & 0.99 & - & 0.08 & 1.06 \\
\hline N sources $(B)$ & $* *$ & $* *$ & NS & $* *$ \\
\hline A. Nitrate & 5.12 & 11.95 & 11.22 & 40.30 \\
\hline Urea & 3.85 & 8.97 & 9.91 & 38.34 \\
\hline A. Sulfate & 4.58 & 10.64 & 10.82 & 39.42 \\
\hline LSD 0.05 & 0.58 & 0.73 & - & 0.47 \\
\hline Interaction $(A * B)$ & $0.97 *$ & $1.26 *$ & NS. & NS. \\
\hline \multicolumn{5}{|c|}{$2016 / 2017$ season } \\
\hline Varieties (V) & NS. & $* *$ & $* *$ & $*$ \\
\hline Sakh 1 & 4.26 & 10.16 & 8.94 & 39.35 \\
\hline Sakh 2 & 4.86 & 11.60 & 9.38 & 40.12 \\
\hline Giza 9 & 3.71 & 9.26 & 7.86 & 38.21 \\
\hline LSD 0.05 & - & 0.44 & 0.85 & 0.92 \\
\hline $\mathrm{N}$ sources $(\mathrm{B})$ & $*$ & $* *$ & $* *$ & $* *$ \\
\hline A. Nitrate & 4.75 & 11.34 & 9.38 & 40.15 \\
\hline Urea & 3.75 & 9.01 & 7.86 & 38.19 \\
\hline A. Sulfate & 4.32 & 10.67 & 8.95 & 39.34 \\
\hline LSD 0.05 & 0.69 & 0.80 & 0.47 & 0.71 \\
\hline Interaction $\left(A^{*} \mathbf{B}\right)$ & $1.20 *$ & NS. & NS. & NS. \\
\hline
\end{tabular}

$* \mathrm{P} \leq 0.05,{ }^{* *} \mathrm{P} \leq 0.01$ and NS.: Not significant. 
TABLE 5. Estimates of simple correlation coefficients in 2015/2016 season (above diagonal line) and in 2016/2017 season (below diagonal line) of straw yield $\left(\right.$ ton fed $\left.^{-1}\right)$ and other related traits.

\begin{tabular}{|c|c|c|c|c|c|c|}
\hline Character & Plant height & $\begin{array}{l}\text { Technical } \\
\text { stem length }\end{array}$ & $\begin{array}{c}\text { Stem } \\
\text { diameter }\end{array}$ & $\begin{array}{c}\text { No of } \\
\text { branches }^{-1} \\
\text { plant }^{-1}\end{array}$ & $\begin{array}{l}\text { Straw yield } \\
\text { plant }^{-1}\end{array}$ & $\begin{array}{l}\text { Straw yield } \\
\mathrm{kg} \mathrm{fed}^{-1}\end{array}$ \\
\hline
\end{tabular}

\begin{tabular}{|c|c|c|c|c|c|c|c|}
\hline \multirow[b]{2}{*}{ Plant height } & & \multicolumn{6}{|c|}{$2015 / 2016$} \\
\hline & & & $0.952 * *$ & $0.428^{*}$ & $0.202^{\mathrm{ns}}$ & $0.770 * *$ & $0.721 * *$ \\
\hline Technical stem length & & $0.902 * *$ & & $0.347^{\mathrm{ns}}$ & $0.224^{\mathrm{ns}}$ & $0.763 * *$ & $0.762 * *$ \\
\hline Stem diameter & $\overline{0}$ & $0.769 * *$ & $0.618^{* *}$ & & $0.466^{*}$ & $0.429 *$ & $0.528^{* *}$ \\
\hline No of branches plant ${ }^{-1}$ & $\overrightarrow{\mathrm{N}}$ & $0.357^{\mathrm{ns}}$ & $0.331^{\text {ns }}$ & $0.428 *$ & & $0.376^{\mathrm{ns}}$ & $0.322^{\mathrm{ns}}$ \\
\hline Straw yield plant ${ }^{-1}$ & & $0.713^{* *}$ & $0.805^{* *}$ & $0.601 * *$ & $0.236^{\mathrm{ns}}$ & & $0.684 * *$ \\
\hline Straw yield $\mathrm{kg} \mathrm{fed}^{-1}$ & & $0.606^{* *}$ & $0.572 * *$ & $0.586 * *$ & $0.137^{\text {ns }}$ & $0.623 * *$ & \\
\hline
\end{tabular}

TABLE 6. Correlation coefficient ( $r)$, coefficient of determination $\left(R^{2}\right)$ and standard error of the estimates (SEE) for predicting straw yield (ton fed ${ }^{-1}$ ) in 2015/2016 and 2016/2017 seasons.

\begin{tabular}{lccccc} 
Season & $\mathbf{R}$ & $\mathbf{R}^{2}$ & SEE & Sig. & Fitted equation \\
\hline $2015 / 2016$ & 0.812 & 0.659 & 0.349 & $* *$ & $\begin{array}{l}\text { Straw yield }\left(\text { ton } \text { fed }^{-1}\right)=-1.192+0.042 \text { technical stem length }+0.530 \\
\text { stem diameter }\end{array}$
\end{tabular}

2016/2017 $0.623 \quad 0.389 \quad 0.489 \quad * * \quad$ Straw yield $\left(\right.$ ton fed $\left.^{-1}\right)=1.203+0.641$ straw yield plant ${ }^{-1}$

Correlation analysis among flax seed yield traits

The simple correlation coefficients between seed yield and related traits in 2015/2016 and $2016 / 2017$ seasons are given in Table 7 . In both seasons, it is clearly evident that seed yield $\mathrm{kg} \mathrm{fed}{ }^{-1}$ positively correlated with number of fruiting branches plant $^{-1}$ fruiting zone length, number of capsules plant ${ }^{-1}, 1000$ seed weight, seed yield plant ${ }^{-1}$, Mn mg $100 \mathrm{~g}^{-1}$, Fe mg $100 \mathrm{~g}^{-1}$, $\mathrm{Zn} \mathrm{mg} 100 \mathrm{~g}^{-1}$, oil \% and oil yield $\mathrm{kg} \mathrm{fed}^{-1}$. These findings are in concordance with those obtained by Tadesse et al. (2009), Kumar \& Paul (2016) and Kumar et al. (2018). Data illustrated in Table 8 clarified that, there are two traits i.e., seed yield plant $^{-1}$ and number of capsules plant ${ }^{-1}$ in the first

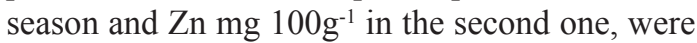
significantly $(\mathrm{P} \leq 0.001)$ contributed to variation in seed yield $\mathrm{fed}^{-1}$. Data revealed that $59.70 \%$ of the total seed yield ${ }^{-1}$ variations could be linearly related seed yield plant ${ }^{-1}$ and number of capsules plant $^{-1}$ in $1^{\text {st }}$ season and $63.00 \% \mathrm{Zn} \mathrm{mg} 100 \mathrm{~g}^{-1}$ in $2^{\text {nd }}$ season. 
TABLE 7. Estimates of simple correlation coefficients in 2015/2016 season (above diagonal line) and in 2016/2017 season (below diagonal line) of seed yield $\left(\mathrm{kg} \mathrm{fed}^{-1}\right)$ and other related traits.

\begin{tabular}{|c|c|c|c|c|c|c|c|c|c|c|c|c|}
\hline Character & & 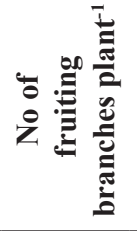 & 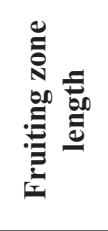 & 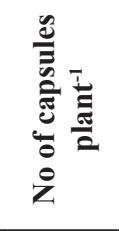 & 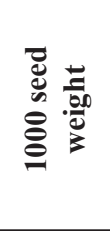 & 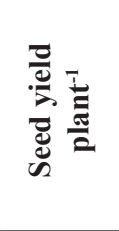 & 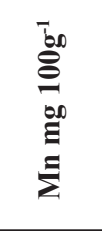 & $\begin{array}{l}\text { bo } \\
\stackrel{0}{0} \\
0 \\
0 \\
\Xi \\
0 \\
0\end{array}$ & 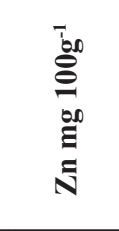 & $\frac{\partial}{\partial}$ & 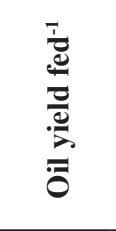 & 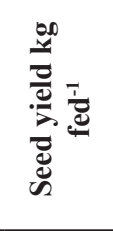 \\
\hline & & \multicolumn{11}{|c|}{$2015 / 2016$} \\
\hline $\begin{array}{l}\text { No of fruiting } \\
\text { branches plant }^{-1}\end{array}$ & \multirow{11}{*}{ 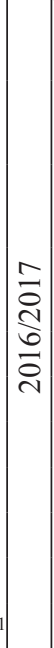 } & & & & & $0.704^{\prime}$ & $0788 *$ & $0.615^{* *}$ & $0.759 *$ & $0.859 * *$ & $0.777 * *$ & 0.742 \\
\hline $\begin{array}{l}\text { Fruiting zone } \\
\text { length }\end{array}$ & & $0.386^{*}$ & & & $.332^{\mathrm{ns}}$ & $0.391 *$ & $0.519 * *$ & $0.220^{\mathrm{ns}}$ & $0.496 * *$ & $0.538 * *$ & $0.500 * *$ & $0.484 *$ \\
\hline $\begin{array}{l}\text { No of capsules } \\
\text { plant }^{-1}\end{array}$ & & $0.758^{* *}$ & $0.424 *$ & & & $0.656^{*}$ & $0.755^{* *}$ & $0.638 * *$ & $0.790 * *$ & $0.815^{* *}$ & $0.753 * *$ & $0.726^{* *}$ \\
\hline $\begin{array}{l}1000 \text { seed weight } \\
(\mathrm{g})\end{array}$ & & $0.868 * *$ & $0.344^{\mathrm{ns}}$ & $0.725 * *$ & & $0.771 * *$ & $0.746^{* *}$ & $0.743 * *$ & $0.743 * *$ & $0.831 * *$ & $0.756 * *$ & $0.727 * *$ \\
\hline Seed yield plant ${ }^{-1}$ & & $0.871 * *$ & $0.508^{* *}$ & $0.637 * *$ & $0.730 * *$ & $x$ & $0.605^{* *}$ & $0.632 * *$ & $0.670 * *$ & $0.777^{* *}$ & $0.793 * *$ & $0.773 * *$ \\
\hline Mn mg100g-1 & & $0.764 * *$ & $0.331^{\text {ns }}$ & $0.556 * *$ & $0.584 * *$ & $0.680 * *$ & $x$ & $0.634 * *$ & $0.698 * *$ & $0.765^{* *}$ & $0.584 * *$ & $0.541 * *$ \\
\hline Fe mg $100 g^{-1}$ & & $0.856^{* *}$ & $0.474 *$ & $0.708 * *$ & $0.822 * *$ & $0.869 * *$ & $0.631 * *$ & $x$ & $0.476^{*}$ & $0.694 * *$ & $0.724 * *$ & $0.711 * *$ \\
\hline Zn mg $100 \mathrm{~g}^{-1}$ & & $0.848 * *$ & $0.443^{*}$ & $0.771 * *$ & $0.830 * *$ & $0.754 * *$ & $0.650 * *$ & $0.805 * *$ & $=x$ & $0.779 * *$ & $0.682 * *$ & $0.652 * *$ \\
\hline Oil \% & & $0.852 * *$ & $0.379^{\mathrm{ns}}$ & $0.756^{* *}$ & $0.853^{* *}$ & $0.713^{* *}$ & $0.679 * *$ & $0.775^{* *}$ & $0.798 * *$ & $x$ & $0.827 * *$ & $0.785^{* *}$ \\
\hline Oil yield fed ${ }^{-1}$ & & $0.728 * *$ & $0.397 *$ & $0.679 * *$ & $0.732 * *$ & $0.596 * *$ & $0.589 * *$ & $0.780 * *$ & $0.823 * *$ & $0.725^{* *}$ & $x$ & $0.997^{* *}$ \\
\hline Seed yield kg fed ${ }^{-1}$ & & $0.683^{* *}$ & $0.381^{\mathrm{ns}}$ & $0.642 * *$ & $0.692 * *$ & $0.558 * *$ & $0.550 * *$ & $0.751 * *$ & $0.794 * *$ & $0.666^{* *}$ & $0.996 * *$ & $x$ \\
\hline
\end{tabular}

TABLE 8. Correlation coefficient ( $r)$, coefficient of determination $\left(R^{2}\right)$ and standard error of the estimates (SEE) for predicting seed yield $\left(\mathrm{kg} \mathrm{fed}^{-1}\right)$ in $2015 / 2016$ and 2016/2017 seasons.

\begin{tabular}{|c|c|c|c|c|c|}
\hline Season & $\mathbf{R}$ & $\mathbf{R}^{2}$ & SEE & Sig. & Fitted equation \\
\hline $2015 / 2016$ & 0.773 & 0.597 & 101.85 & $* *$ & $\begin{array}{l}\text { Seed yield }\left(\mathrm{kg} \mathrm{fed}^{-1}\right)=12.08+246.66 \text { seed yield plant }^{-1}+13.947 \text { No. of capsules } \\
\text { plant }^{-1}\end{array}$ \\
\hline $2016 / 2017$ & 0.794 & 0.630 & 112.05 & $* *$ & Seed yield $\left(\mathrm{kg} \mathrm{fed}^{-1}\right)=-594.48+136.81 \mathrm{Zn} \mathrm{mg} 100 \mathrm{~g}^{-1}$ \\
\hline
\end{tabular}

\section{Conclusion}

The present investigation was carried out to study the effect of $\mathrm{N}$-sources on three flax cultivars straw and seed yield as well as seed quality. The gained results indicated that Sakha-1 gave the highest mean values of straw yield and related traits. While, the cultivar Sakha-2 was exceeded other flax cultivars in seed yield and related traits. Ammonium nitrate followed by ammonium sulfate as $\mathrm{N}$-sources gave the highest straw and seed yield and its related traits when compared with urea. Thus, the recommendations of this study are cultivating Sakha-2 variety and fertilized by ammonium nitrate as $\mathrm{N}$-sources.

\section{References}

Abou-Zaied,T.A. and Mousa, A.M. (2007) Effect of different NPK treatments on yield and yield components of two flax varieties. J. Agric. Sci. Mansoura Univ. 32(10), 8057-8064.

Afifi, M.H., Khalifa, R.Kh.M., Khattab, E.A. and ElDewiny, Camilia Y. (2014) Response of two flax cultivars to different sources of organic and bio fertilizers addition under newly reclaimed sandy soil conditions. Middle East Journal of Agriculture Research, 3(2), 311-317.

A.O.A.C. (1990) "Official Methods of Analysis". 15 ed., Association of Official Agricultural Chemists, 
Washington, D.C., U.S.A.

Bakry, A.B. (2009) Effect of seeding rate on yield and quality traits of some flax varieties (Linum usitatissimum L.) grown in newly reclaimed sandy soil. Ph.D. Thesis. Cairo Unive. Egypt.

Bakry, A.B., Nofal, O.A. and Zeidan, M.S. (2012) Agronomic characteristics of three flax varieties as affected by some sources of potassium fertilization under newly reclaimed sandy soil conditions. Australian Journal of Basic and Applied Sciences, 6(4), 77-81.

Bakry, A.B., Nofal, O.A., Zeidan, M.S. and Hozayn, M. (2015) Potassium and zinc in relation to improve flax varieties yield and yield components as grown under sandy soil conditions. Agricultural Sciences, 6, 152-158.

Chapman, H.D. and Pratt, P.F. (1961) "Methods of Analysis for Soil, Plants and Water", pp. 56-63. University of California, Division of Agricultural Science, Berkeley, CA, USA.

Conforti, F.D. and Cachaper, K.F. (2009) Effects of selected antioxidants on physical and sensory characteristics of yeast bread containing flaxseed meal. Int. J. Cons Stud. 33, 89-93.

Egyptian Ministry of Agriculture (2007) The bulletin of growing flax, No. 1086.

Elayan, Sohair E.D., Abdallah, Amany M., Naguib, Nemat A. and Mahmoud, Doaa I. (2015) Effect of sowing date on yield, fiber and seed quality of eight flax genotypes. American-Eurasian J. Agric. \& Environ. Sci. 15 (5), 886-895.

El-Azzouni, A.M.A. and Zedan, Z.A. (2009) Effect of sowing dates, foliar $\mathrm{x}$ as balanced compound fertilizer on yield and its components some flax varieties in sandy soil. J. Agric. Sci., Mansora Univ. 20(3), 2071-2084.

El-Borhamy, Amal M.A. (2016) Effect of seeding rates and nitrogen fertilizer levels on yield and yield components of two new flax cultivars. J. Agric. Res. Kafr El-Sheikh Univ. 42(2), 183-195.

El-Seidy, E.H., El-Refaey, R., AAbou-Zaied, T., A.Abd El-Razek, U.A. and Rashwan, E. A. (2015) Effect of different mineral and biological nitrogenous fertilizers combinations on seed yield and its components of some flax 'Linum usitatissimum L.' genotypes. Glob. J. Agric. Food Safety Sci. 2(3), 180-198.

El-Shafey, Amina I. and Hassan, Sanaa S. (2016) Impact of ascorbic and folic acids foliar application on yield, growth and its attributes of flax cultivars. Alex. J. Agric. Sci. 61(2), 61-72.

El-Shazly, M.A., El-Dissoky, R.A. and Awaad, M.S. (2014) Effect of soil amendments and nitrogen fertilizer sources on sugar beet productivity grown salt affected soil conditions. J. Soil Sci. Agric. Eng. Mansoura Univ. 5(2), 267-278.

Gallardo, M.A., Milisich, H.J., Drago, S.R. and González, R.J. (2014) Effect of cultivars and planting date on yield, oil content, and fatty acid profile of flax varieties (Linum usitatissimum L.). International Journal of Agronomy, 2014. Article ID: 150570, 7 pages.http://dx.doi. org/10.1155/2014/150570

Gomez, K.A. and Gomez A.A. (1984) "Statistical Procedures for Agricultural Research", Wiley and sons, New York.

Grant, C.A., McLaren, D., Irvine, R.B. and Duguid, S.D. (2016) Nitrogen source and placement effects on stand density, pasmo severity, seed yield and quality of no-till flax. Can. J. Plant Sci. 96, 34-47.

Hall, C., Tulbek, M.C. and Xu, Y. (2006) Flaxseed. $A d v$ Food Nutr. Res. 51, 1-97.

Homayouni, G., Souri, M. and Zarein, M. (2013) Effects of zinc and nitrogen on yield components of five flax genotypes. Global Journal of Science Frontier Research Chemistry, 13(5), 20-24.

Kandil, A.A., Hoballah, A.A., El-Hariri, D.M. Zeidan, M.S. and Bakry, A.B. (2008) Effect of seeding rate on yield and quality traits of some flax varieties (Linum usitatissmum L.) grown in newly reclaimed sandy soils. Egypt J. Appl. Agric. Res. (NRC), 1(1), 69-81.

Karg, S. (2011) New research on the cultural history of the useful plant Linum usitatissimum L. (flax), a resource for food and textiles for 8,000 years. Vegetation History and Archaeobotany. 20(6), $507-$ 508.

Khan, M.L., Sharif, M. Sarwar, M., Sameea and 
Ameen, M. (2010) Chemical composition of different varieties of linseed. Pakistan Veterinary $J$. 30(2), 79-82.

Khalifa, R.Kh.M., Manal, F.M., Bakry, A.B and Zeidan, M.S. (2011) Response of some flax varieties to micronutrients foliar application under newly reclaimed sandy soil. Australian Journal of Basic and Applied Sciences, 5(8), 1328-1334.

Kumar, N. and Paul, S. (2016) Selection criteria of linseed genotypes for seed yield traits through correlation, path coefficient and principal component analysis. The Journal of Animal \& Plant Sciences, 26(6), 1688-1695.

Kumar, S., Sharma, A.,Choudhary, A., Purushottam, M. and Chauhan, M.P. (2018) Applying correlation and path coefficient to study genetic variability in linseed (Linum usitatissimum L.). Journal of Pharmacognosy and Phytochemistry, 7(2), 25932595.

Millis, P. (2002) Nutrition, cooking and health: Let's eat flax. Whole-ness and Wellness J. Saskatchewan, 8, 8-9.

Mirshekari, M., Amiri, R., Nezhad, H.I., Noori, S.A. S. and Zandvakili, O.R. (2012) Effects of planting date and water deficit on quantitative and qualitative traits of flax seed. American-Eurasian J. Agric. \& Environ. Sci. 12(7), 901-913.

Nawar, A., Abou-zied, K. and Khalil, H. (2017) Impact of tillage intensity, NPK fertilization and weed control on seed yield and yield components of flax in newly reclaimed lands. Egypt. J. Agron. 39(2), 179-194.

Sharief, A.E., EL-Hindi, M.H., EL- Moursy, S.A. and Seadh, A.K. (2005) Response of two flax cultivars to N, P and K fertilizer levels. Scientific Journal of King Faisal University (Basic and Applied Sciences), 6(1), 127-144.

Sadi, Gökhan BurhanKarabakan and Muhammad Aasim (2017) Biochemical characterization of four different genotypes of Flax (Linum usitatissimum L.) seeds. Anatolian Journal of Botany, 1(1), 12-17.

Santos, R.F., Borsoi, A., Secco, D., Melegari de Souza, S.N. and Frigo, E.P. (2012) Nitrogen and sulfur sources in the culture of Brassica napus L. var. oleifera. J. of Food, Agriculture \& Environment, 10(1), 516-518.

Soethe, G., Feiden, A., Bassegio, D., Santos, R.F., Melegari de Souza, S.N. and Secco, D. (2013) Sources and rates of nitrogen in the cultivation of flax. African Journal of Agricultural Research, 8(19), 2249-2253.

Tadesse, T., Singhi, H. and Weyessa, B. (2009) Correlation and path coefficient analysis among seed yield traits and oil content in Ethiopian linseed germplasm. Int. J. Sustain. Crop Prod. 4(4), 08-16.

Wilde, S.A., Corey, R.B., Lyer, J.G. and Voigt, G.K. (1985) "Soil and Plant Analysis for Tree Culture", $3^{\text {rd }}$ ed., pp. 93-106. Oxford and IBM Publishers, New Delhi, India.

Zaki, M.S., El-Sarag, Eman I., Maamoun, Howaida A. and Mubarak, M.H. (2018) Agronomic performance sugarbeet (Beta vulgaris L.) in Egypt using inorganic, organic and biofertilizers. Egypt. J. Agron. 40(1), 89-103. 


\section{البيئة أجافافيناف الكتان (Linum usitatissimum L.) لمصادر مختلفة من النيتروجين في}

صلاح الدين محمد إمام

قسم المحاصيل ـ كلية الزين مدرامة ـ إمامعة الفيوم - الفيوم - مصر.

اقيمت تجربتين حقليتين فى مزر عة دمو، كلية الزر اعة، جامعة الفيوم، مصر ، خلال موسمى 2016/2015 و

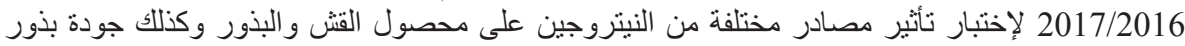

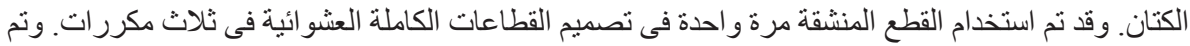

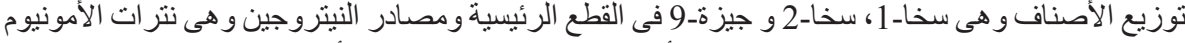

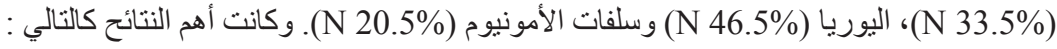

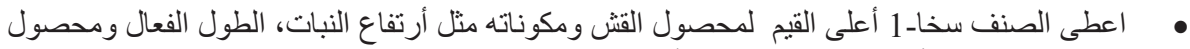

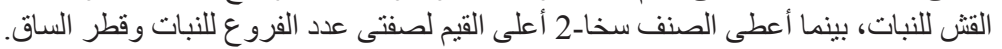

تخطى الصنف سخا-2 كل الأصناف فى محصول البذور ومكوناته مثنل طول المنطقة الثمرية، عدد الفروع

الثمرية، عدد الكبسو لات للنبات، وزن 1000 بذرة، محصول البذور للنبات ومحصول الزئل الزيت للفدان.

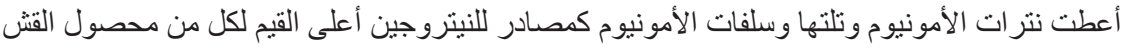
و البذور و الصفات المرتبطة بهما عند مقارنتها باليوريا.

يوصى بزر اعة الصنف سخا-2 مع التسميد بسماد نتر ات الأمونيو كمصدر للأزوت.

اظهرت نتائج تحليل الأرتباطوجود أرتباط عالى المعنوية بين محصول القش للفدان وكل من ارتفاع النبات

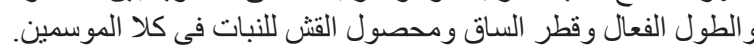

خلال موسمى الزر اعة، كان هنالك أرتباط عالى المعنوية بين محصول البذور للفدان وكل من عدد الفروع

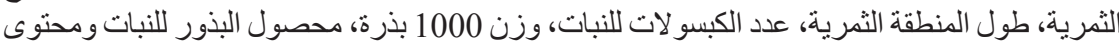

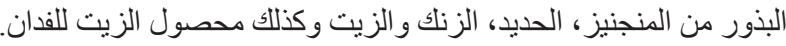

